\title{
COLOUR PATTERNS OF SYRPHIDAE: IV. MIMICRY AND VARIATION IN NATURAL POPULATIONS OF ERISTALIS TENAX
}

\author{
J. R. HEAL* \\ Department of Biological Scieıces, Keele University
}

Received 16.xi.81

\section{SUMMARY}

The dronefly, Eristalis tenax L., and the honeybee, Apis mellifera L., are similar in their general form, flight and coloration. Experiments with captive birds showed that $E$. tenax are very palatable, although they may be avoided if given after honeybees. Thus the mimicry is of the Batesian variety.

Both model and mimic vary in colour pattern. Although the phenotypic variation is continuous, in both species it is also bimodal owing to genetic polymorphisms which are modified by other factors. In north-west England the overall percentage of "light" patterns was roughly 50 per cent, both in the model and in the mimic. Pattern frequencies in $E$. tenax were fairly consistent between samples, as expected for a highly mobile species, but honeybees showed local fluctuations. In spring, $E$. tenax was less variable, and much less numerous, than it was in autumn.

Although similar in colour, the markings on the abdomens of the two species differ in shape. Possible reasons why Eristalis tenax has not evolved a more exact resemblance to Apis mellifera are that the modified patterns derive some added protection from a partial mimicry of wasps, and that they are more effective in temperature regulation.

\section{INTRODUCTION}

DIVERSITY is most easily understood when the benefits of alternative phenotypes can be visualised. For this reason, students of evolution have long been attracted to insect mimicry. In the case of a defenceless Batesian mimic, whose protection is dependent on the presence of a noxious model, the advantage of a particular pattern will decline as it becomes more numerous. Thus a polymorphism may evolve if there are several potential models. In some swallowtail butterflies distinct mimetic patterns are controlled by a series of supergenes, although the mimicry tends to be poorly developed or absent where models are scarce (see Sheppard, 1975; Turner, 1977). However, both theory and experiment indicate that mimicry can still occur when mimics outnumber their models, and also that imperfect resemblances can provide some protection against predation (Holling, 1965; Mostler, 1935; Brower, 1960; Duncan and Sheppard, 1965).

Worker honeybees (Apis mellifera L.) are protected by their stings against many predators, e.g., toads (Cott, 1936; Popham, 1948), and the venom is unpalatable even if the sting is not used (Liepelt, 1963). Bees are the models for several Dipteran mimics. Brower and Brower (1962, 1965) showed that an American hoverfly, Eristalis vinetorum, was acceptable to naive toads but was rejected by toads trained to avoid honeybees.

\footnotetext{
* Present address: Science Department, Marshlands High School, Milehouse Lane, Newcastle-under-Lyme, Staffordshire.
} 
Rejection of the flies was partly visual, but buzzing of the wings also contributed.

The dronefly Eristalis tenax L. mimics the honeybee in form, coloration and behaviour. The abdomen can be dark brown or extensively orange, but there is continuous variation between these extremes. Breeding studies (Heal, 1979) showed that an allele for light patterns $\left(A p^{L}\right)$ is dominant to the dark allele $\left(A p^{d}\right)$. The two morphs are not always discrete owing to variation within each morph attributable to secondary genes and environmental factors (e.g., rearing temperatures). There is also a sex difference in expression; males tend to have lighter patterns.

Apart from a difference in the shape of the light markings, the variability of E. tenax and of Apis mellifera in Britain is comparable. Golden-banded honeybees ("yellows"), principally "Italian bees" of the ligustica race, have been imported since 1859 and now, after over a century of hybridisation with the very dark brown varieties ("blacks"), British bees are quite variable in colour (Mace, 1976).

$E$. tenax are active during much of the year, from March to early December, and sometimes are far more numerous than foraging honeybees, especially at urban sites in autumn. There are at least three generations each year. Males are very scarce in spring when fertilised females emerge from hibernation. Males and females occur in roughly equal numbers in summer and autumn.

This paper describes the variation observed in natural populations of Eristalis tenax in north-west England, and relates the polymorphism in the fly to the colour variation in honeybees in the same areas. It is also shown that droneflies are palatable to birds, and so are Batesian mimics of Hymenopteran models.

\section{MATERIALS AND METhodS}

(i) Field work

The sites used for field work were as follows: (a) Several areas of derelict land in central Liverpool. At these urban sites $E$. tenax visited mainly yellow composite flowers such as Tussilago farfara, Senecio squalidus, Leontodon autumnalis and Taraxacum officinale. Honeybees also visited these sites, particularly from June to August when they foraged at Rosebay Willow-herb (Chamaenerion angustifolium). (b) Formby dunes (Merseyside). (c) The Wirral peninsula, including Liverpool University Botanic Gardens at Ness, where a wide variety of flowers was available during most of the year, and also along the Wirral Way footpaths. (d) Parts of north Cheshire around the Delamere Forest. (e) North Staffordshire, principally on the campus of Keele University, where there were garden flowers as well as wild composites.

In rural areas E. tenax were often on Senecio jacobaea or Rubus fruticosus, but they rarely occurred anywhere distant from human habitations, probably because human or animal sewage are the main sources of larval food (Lundbeck, 1916).

Colour pattern frequencies were assessed by two methods which gave similar results. Flies were collected when they were feeding on pollen or nectar at flowers, or resting on walls, bare ground or vegetation ("collec- 
tions"). Notes were also kept on all flies observed during surveys of the study areas ("observations").

\section{(ii) Classification of patterns: Eristalis tenax}

The colour patterns of $E$. tenax were classified into six arbitrary grades (UL, L, ML, M, MD, D). The markings on the adbomen become progressively smaller and darker through this series. Grades UL and L have orange areas on tergites 2 and 3; ML, M and MD have orange or brown markings on tergite 2 only; grade D is entirely dark (see fig. 1). Fuller definitions and diagrams were given in a previous paper (Heal, 1979).

Apis

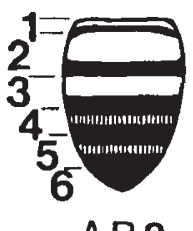

AB 2

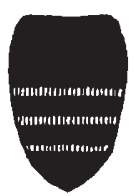

A D

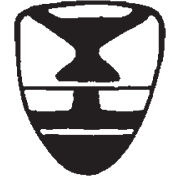

$U \mathrm{~L}$

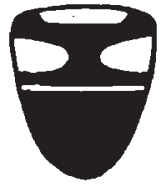

M

\section{Eristalis}

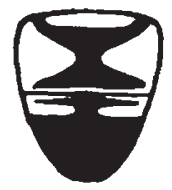

$\mathrm{L}$
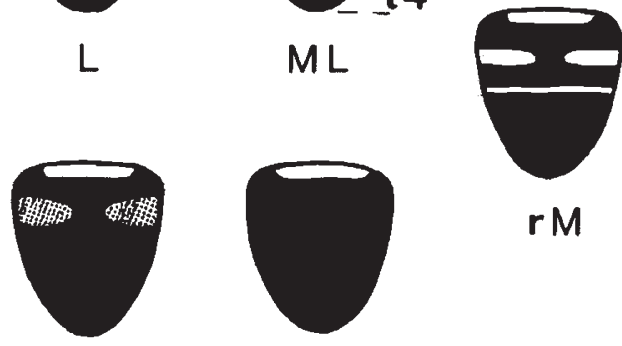

$r M$

FIG. 1.-Diagrams of the abdomens of honeybees (Apis) and droneflies (Eristalis). Apis: The two commonest forms are shown. Segments of abdomen are numbered. Eristalis: Six principal grades of colour pattern are represented, and also the "rM" pattern found in spring samples. Tergites of abdomen $(t 1-4)$ indicated. Tergite 1 is dark but lies under the scutellum. Heavy shading = black or dark brown. Stippled = dull brown. Unshaded = light brown, orange or golden. Vertical hatching (Apis only) $=$ bands of pale hairs on dark cuticle.

Breeding experiments showed that, in general, flies homozygous for the dark allele $\left(A p^{d} A p^{d}\right)$ fell within the grades M, MD or D, if male; but within MD or $\mathrm{D}$ only, if female. Although there was a slight phenotypic overlap between dark homozygotes and flies carrying the dominant light allele, for practical purposes the following division was made:

$$
\begin{array}{lll}
\text { Light Phenotype (L. ph.) } & \text { o } & \text { UL, L, ML } \\
& \text { क } & \text { L, ML, M } \\
\text { Dark Phenotype (D. ph.) } & \text { o } & \text { M, MD, D } \\
& \wp & \text { MD, D . }
\end{array}
$$

The different demarcation for males and females should be noted. UL females are not included because they did not occur in the populations studied. 
One pattern that did not fit neatly into the classification scheme is termed "rM" (reduced Medium); the light brown markings are narrower than in standard $M$, but brighter than in $M D$. This " $r M$ " pattern was frequent in spring samples of females, but was otherwise uncommon, suggesting that some modification can occur prior to or during hibernation.

\section{(iii) Classification of patterns: honeybees}

A different scheme was used to assess pattern variation in foraging honeybees. This was done because the light markings on the abdomen of Apis workers tend to occur as broad transverse bands across the tergites, whereas in Eristalis the markings comprise pairs of semi-oval spots separated by a median black area, with narrow pale bands along the rear margins of some tergites.

In 1977-1979 the following scheme was used for honeybees (see fig. 1): AD Tergites of abdomen entirely black. AC Some lighter areas on tergite 2, but these are obscured or restricted to the corners. AB1 One clear orange or light brown band on tergite 2. AB2 Two clear bands on tergites 2 and 3; rarely, a further band on tergite 4 . In the brightest specimens the bands are golden. The first tergite is small and not easily seen from above, but it is usually dark in $\mathrm{AD}$ and $\mathrm{AC}$, and lightly pigmented in $\mathrm{AB} 1$ and $\mathrm{AB} 2$.

Banded bees in north-west England are not as brightly coloured as the extreme type of ligustica, for the rearmost tergites are usually dark. The bands on tergites 2-4 vary in extent and tone, but were classified principally by their extent, except that a very dull band could be overlooked during field observation. Apis workers also have rows of pale hairs across the middle of tergites 3,4 and 5. These bands of hairs are not present on Eristalis tenax.

Although the abdomens of model and mimic differ as described here, these differences are not obvious when the insects are active. The similar form and general colour still create a strong resemblance.

\section{(iv) Experiments on mimicry}

Some experiments were carried out in an indoor aviary (size: $1.50 \times$ $1.10 \times 0.90 \mathrm{~m}$ ). Insect prey were immobilised by removal of legs and wings, and placed on a tray in the corner of the cage. The birds could examine the shape and colour of the insects, but behavioural components of the mimicry were unimportant. Most of the work was done with a robin (Erithacus rubecula); some preliminary tests involved two house sparrows (Passer domesticus). Insects were also fed to wild birds, principally great tits (Parus major).

\section{Results}

\section{(i) Batesian mimicry}

Eristalis tenax are very palatable to birds. In February 1976 a pair of great tits took $22 E$. tenax from a window ledge, although the flies were left untouched by blue tits and house sparrows. Two captive house sparrows were presented with tethered $E$. tenax; none of the first ten were taken, 
but after one had been tried, all others were eaten. In the next five weeks, 63 were taken by the sparrows and other Syrphids given subsequently (Eristalis arbustorum L., Metasyrphus luniger (Meig.)) were also eaten. The initial avoidance could have been due to the flies' bee-like appearance, but possibly the sparrows were just not used to taking insect prey.

A captive robin ate the first $E$. tenax that it was given. Hoverflies were regularly preferred to other Diptera, possibly because of their less bristly surface, but were not as palatable as mealworms (larvae of Tenebrio molitor). After two months of palatable insects, the robin was offered some Apis mellifera workers. The bees had been kept in a freezer and their stings were removed before the experiment. Although no live bees were used, these inactive ones were treated very cautiously by the robin; some were eaten but they were always picked up and rejected several times, then pecked, broken into pieces and rubbed on the ground before being swallowed. Flies were usually picked up once and swallowed whole.

TABLE 1

Experiments on the selection of insects by a robin. Unless indicated otherwise, two immobilised specimens of each species were offered, and eaten, in each trial; a dash means that the species was not given. The "preference rankings" were worked out-for the two flies of each speciesfrom the sum of their places in the order in which the flies were eaten; the species with the smallest sum was ranked first. Honeybees were given to the robin for the first time between trials 5 and 6

\begin{tabular}{|c|c|c|c|c|c|c|c|c|c|c|}
\hline \multirow{3}{*}{$\begin{array}{l}\text { Trial number } \\
\text { Days after trial } 1 \text { : }\end{array}$} & \multicolumn{5}{|c|}{ Period I } & \multicolumn{5}{|c|}{ Period II } \\
\hline & 1 & 2 & 3 & 4 & 5 & 6 & 7 & 8 & & 10 \\
\hline & 0 & 3 & 15 & 17 & 22 & 34 & 35 & 36 & 37 & 45 \\
\hline \multicolumn{11}{|l|}{ Preference rankings: } \\
\hline E. tenax $(\mathrm{T})$ & $=1$ & $=1$ & 1 & - & - & 3 & 3 & $=1$ & 3 & 3 \\
\hline E. arbustorum (A) & $=1$ & $=1$ & 2 & 1 & 1 & 2 & 2 & $=1$ & 2 & 1 \\
\hline Calliphora (C) & 3 & 3 & 3 & 2 & 2 & 1 & 1 & $=1$ & 1 & 2 \\
\hline First fly taken & $\mathrm{T}$ & $\mathrm{T}$ & $\mathrm{T}$ & $A$ & A & $\mathrm{C}$ & $\mathrm{C}$ & $\mathrm{C}$ & $\mathrm{C}$ & $\mathrm{C}$ \\
\hline \multirow[t]{2}{*}{ Honeybees eaten } & - & - & - & - & - & 2 & 1 & - & - & 一 \\
\hline & \multicolumn{5}{|c|}{ Period III } & \multicolumn{5}{|c|}{ Period IV } \\
\hline Trial number & 11 & 12 & 13 & 14 & 15 & 16 & 17 & 18 & 19 & 20 \\
\hline Days after trial 1 : & 46 & 48 & 49 & 50 & 51 & 55 & 56 & 58 & 63 & 67 \\
\hline \multicolumn{11}{|l|}{ Preference rankings: } \\
\hline E. tenax $(\mathrm{T})$ & 2 & $=2$ & 3 & 2 & 1 & 2 & 1 & 1 & 2 & 1 \\
\hline E. arbustorum (A) & 1 & $\overline{1}$ & 1 & 1 & 2 & 3 & 2 & 2 & 1 & 2 \\
\hline Calliphora (C) & 3 & $=2$ & 2 & 3 & 3 & 1 & 3 & 3 & 3 & 3 \\
\hline First fly taken & A & A & A & A & $\mathrm{T}$ & $\mathrm{C}$ & $\mathbf{T}$ & $\mathrm{T}$ & A & $\mathbf{T}$ \\
\hline Honeybees eaten & 1 & 2 & 1 & 2 & 2 & 0 & 0 & - & - & - \\
\hline
\end{tabular}

Table 1 summarises the results of a series of experiments and compares the robin's response to the model (Apis mellifera), good mimic (E. tenax), poor mimic (E. arbustorum) and non-mimic (bluebottle, Calliphora spp.). Prior to experience with bees, the robin preferred both Eristalis species to Calliphora (Period I). Eleven other trials during this period showed that other Syrphids (e.g., Syrphus, Helophilus species) were also more acceptable than bluebottles. After the robin had been given some honeybees on four occasions (days 30-33), Calliphora was preferred for a few trials (period II), then $E$. arbustorum (in Period III), and finally $E$. tenax was taken most readily. Thus there was a period of mimetic protection before the robin 
learnt to discriminate, firstly between model and poor mimic, and then between model and good mimic. The changes in behaviour were significant (table 2). The final choice of $E$. tenax over $E$. arbustorum may have been due to larger size. Bees were never touched until all flies had been taken except once in trial 12 , when the robin picked up and rejected a bee immediately after eating an $E$. tenax.

TABLE 2

Selection of insects by a robin, showing the changes of preference as a result of experience. Figures are for the total numbers of each species of fly amongst the first three flies eaten in each trial. Data are as in table 1

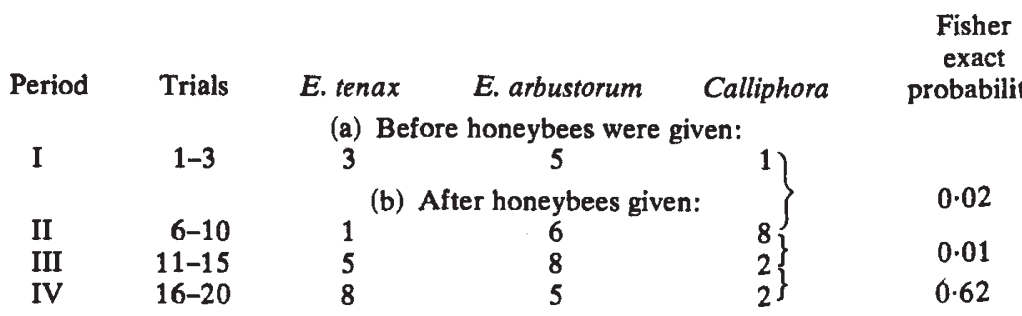

A case of Batesian mimicry was indicated by these experiments, but the effect did not last long, probably because the bees had no stings and the robin had time to inspect all the insects. It was not clear what led to the initial rejection of the bees, unless some taste or texture on the surface elicited an innate response or recalled some previous experience in the wild. The behaviour of captive juvenile reed warblers, Acrocephalus scirpaceus, towards their first wasps showed an innate avoidance, probably on the basis of colour, shape and texture (Davies and Green, 1976), although juvenile birds of some species made more attacks on bees and wasps than older birds did (Mostler, 1935).

\section{(ii) Natural populations of E. tenax-summer and autumn generations}

Eristalis tenax is a Syrphid that becomes common late in the year, and so most estimates of phenotype frequencies were done then. In Liverpool there seemed to be, from late May onwards, a small summer generation derived from overwintered females, followed by an abundant autumn generation, individuals of which either produced a further generation or went into hibernation.

The autumn generation started to appear in August, but the very large increase in the central Liverpool populations that took place in mid-August of four consecutive years may have been helped by some migration into the city from surrounding areas. A recapture rate of under 2 per cent for marked specimens released in Liverpool and at Keele suggested high mobility. Migrations of $E$. tenax have been noted previously by Aubert $e t$ al. (1976), Jones (1955) and Williams (1958). 
In woodlands or open agricultural areas, population densities were always low. However, in late autumn large numbers were recorded on patches of flowers at Ness Gardens and Keele University. Some other Eristalis species, especially $E$. pertinax Scopoli, were at the same flowers, but $E$. tenax was still abundant later in the autumn. In urban areas $E$. tenax and $E$. pertinax tended to use different food sources; $E$. pertinax was often present in parks and gardens but rarely visited the nearby areas of wasteground favoured by E. tenax.

Data on colour patterns in autumn collections from three areas (table 3 ), and more extensive data for all field observations (table 4) are shown. Most sets of figures show a bimodal distribution. In general, the two modes are at $\mathrm{L}$ and $\mathrm{MD}$ or $\mathrm{D}$ for males, but at $\mathrm{M}$ or $\mathrm{D}$ for females. As the lighter female mode coincides with the male antimode, the bimodality is seen to be genuine and not just an artefact of scaling. This differential bimodality, with males lighter on average, agrees with the results of breeding experiments (Heal, 1979). The different demarcation between Light and Dark Phenotype in the two sexes (see Classification of Patterns) is therefore justifiable. It also provides good agreement for $\mathrm{D}$. ph. frequencies in males and in females for most sets of figures in tables 3 and 4.

Data for different months in any one locality have been combined in the tables because the $\mathrm{D}$. ph. frequency did not vary significantly through the annual flight period. The only exception was at Keele in 1977 when there was an excess of darker flies active at the end of the season, in November. In some, but not all, years the position of the modes changed slightly from month to month. Environmental changes might have been the cause of this. Pupal temperature can modify the adult pattern (Heal, 1977 and in preparation) as has already been shown for Eristalis arbustorum (Heal, 1981).

For field observations (table 4), the highest Dark Phenotype estimate is 69 per cent for Liverpool in 1973, but other values fell between 48 per cent and 63 per cent. The contingency table for numbers of L. ph. and D. ph. in all 13 sets of data has a highly significant heterogeneity $\chi_{12}^{2}$ of $48.4(P<0 \cdot 001)$, but if the high $\mathrm{D}$. ph. figures from Liverpool in 1973-1974 are excluded $\chi_{10}^{2}=8.58(P>0.50)$. Liverpool was the only area with heterogeneity between years, $\chi_{3}^{2}=20 \cdot 5, P<0.0001$, for $1973-1976$. However, for 1974-1976 only, $\chi_{2}^{2}=2 \cdot 14(P>0 \cdot 30)$. Thus the major source of variation in the figures is a higher proportion of dark flies in earlier data from Liverpool. This may reflect a genuine frequency change; however, the earliest field estimates are likely to have been the least accurate.

The frequency of the Dark Phenotype was slightly higher in Liverpool than on the Wirral in 1973-1975; the difference is significant for 1973 $\left(\chi_{1}^{2}=9 \cdot 59, P<0.01\right)$ and for $1974\left(\chi_{1}^{2}=4.98, P<0.05\right)$, but not for 1975 $\left(\chi_{1}^{2}=0.78, P>0.3\right)$. Looking at all five areas in table 4 , there is a slight tendency for the D. ph. frequency to decrease southwards. However, data from collections (table 3) do not show a cline. Overall, the percentage of Dark Phenotype was 52 per cent in Liverpool, 51 per cent on the Wirral peninsula, and 55 per cent in north Staffordshire. In each area, data from different years were not significantly different and there was no heterogeneity between the sexes in any year sample.

The figures in tables 3-4 suggest that the frequency of the $A p^{d}$ allele is between 0.7 and 0.8 in north-west England. 
J. R. HEAL

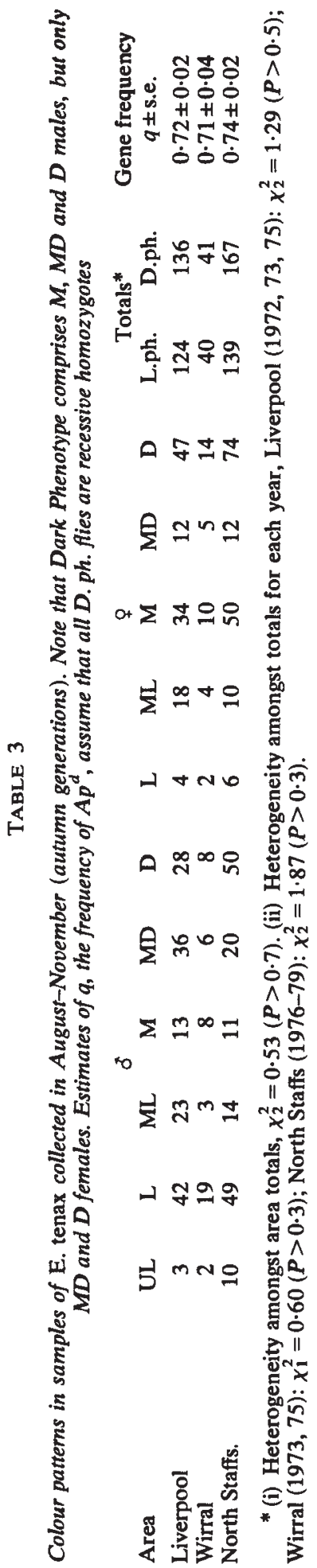




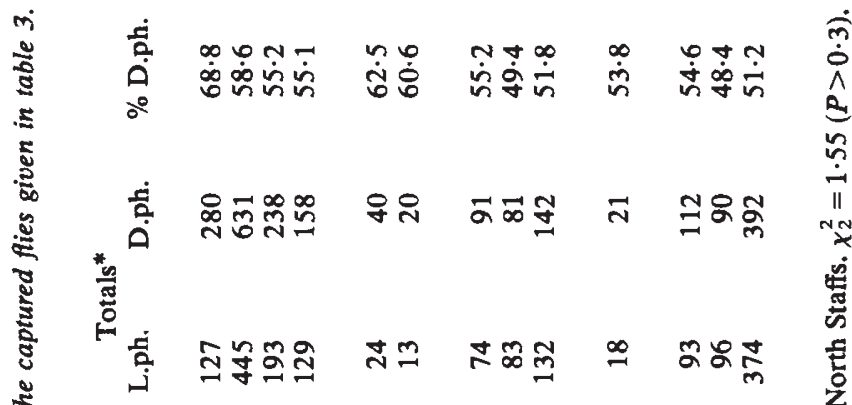

ఫัँ 气

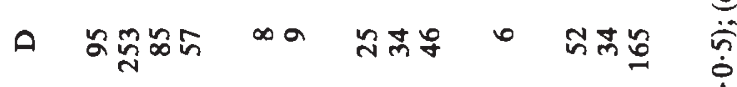

要

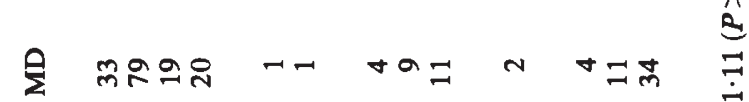

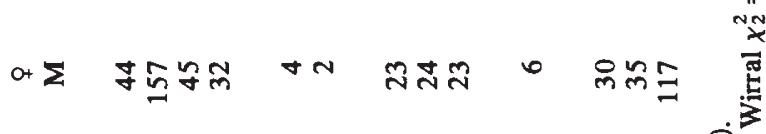

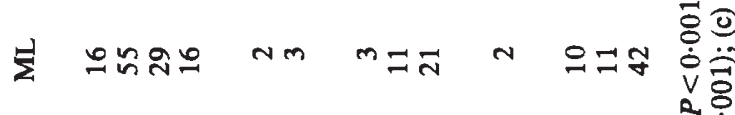

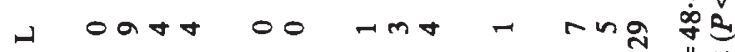

हैं

ค 응요 mo ニำ

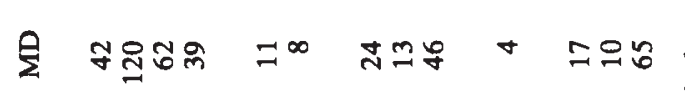

惫宫

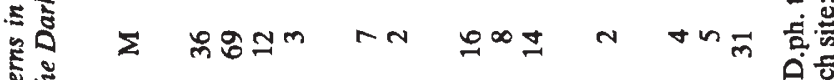

ro

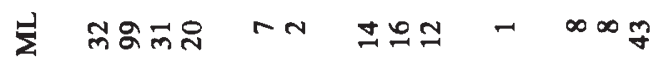

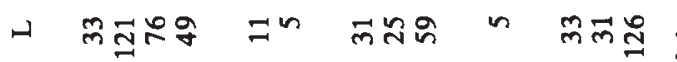

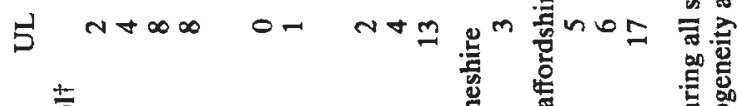

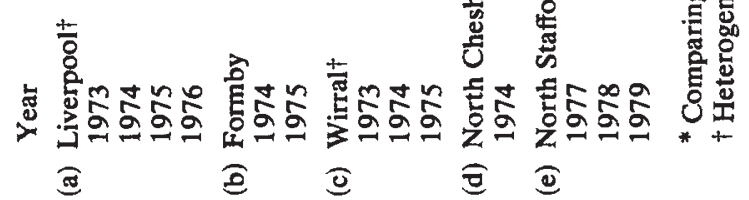


J. R. HEAL

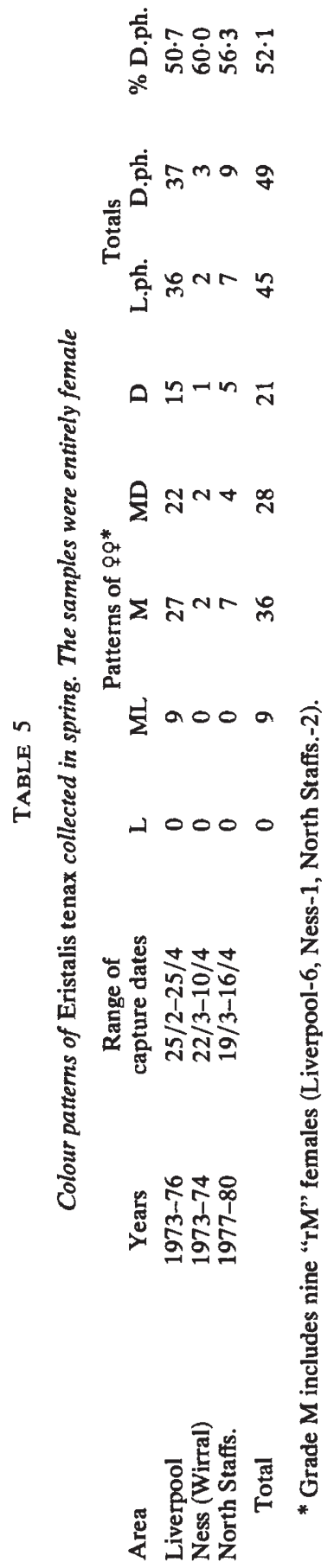




\section{(iii) Natural populations-spring females}

Eristalis tenax is one of the first British Syrphids to appear in the spring. The earliest ones are adults coming out of hibernation, principally fertilised females whose ovarian development has been suppressed by short daylengths (Kendall and Stradling, 1972; Heal, 1977). No males were seen in March or April of any year. Females were collected to initiate breeding stocks; the majority were from urban sites. In each year there was a unimodal distribution of patterns, and consequently the division into two morphs could not be made reliably (table 5). Grades M and MD were the most numerous, but there were some flies with unusual markings (e.g., those scored "rM"). These two facts suggest that changes occur in the patterns during the winter.

Unfortunately, in spring the numbers obtainable from these towns in northern England were smaller than at sites in southern England (Jones, 1955; Dr D. A. Kendall, pers. comm.). This could be due to seasonal migrations, as described for several British butterflies (Baker, 1978; Williams, 1958).

\section{(iv) Surveys of honeybees}

Detailed surveys of honeybees at Keele University campus (1977-1979) indicated a bimodal distribution of colour patterns. Although other types were quite numerous, most workers were either completely dark, or twobanded (table 6).

\section{TABLE 6}

Field observations of Apis mellifera workers and comparisons with E. tenax. Data from sites around Keele, north Staffordshire. See text for classification and explanation of the comparisons made. Note that banded bees are compared with the four lightest grades of fly pattern, not with the Light Phenotype category

\begin{tabular}{|c|c|c|c|c|c|c|}
\hline \multirow[b]{2}{*}{ Year } & \multicolumn{2}{|c|}{ Banded Apis } & \multicolumn{2}{|c|}{ Dark Apis } & \multirow{2}{*}{$\begin{array}{c}\text { Apis } \\
\% \text { banded }\end{array}$} & \multirow{2}{*}{$\begin{array}{l}\text { E. tenax* } \\
\% \text { UL-M }\end{array}$} \\
\hline & AB2 & AB1 & $\mathrm{AC}$ & $A D$ & & \\
\hline $\begin{array}{l}1977 \\
1978 \\
1979\end{array}$ & $\begin{array}{r}260 \\
90 \\
22\end{array}$ & $\begin{array}{r}88 \\
40 \\
7\end{array}$ & $\begin{array}{l}83 \\
58 \\
32\end{array}$ & $\begin{array}{r}210 \\
175 \\
65\end{array}$ & $\begin{array}{l}54 \cdot 3 \\
35 \cdot 8 \\
23 \cdot 0\end{array}$ & $\begin{array}{l}47 \cdot 3 \\
53 \cdot 8 \\
52 \cdot 9\end{array}$ \\
\hline Total & 372 & 135 & 173 & 450 & 44.9 & $52 \cdot 1$ \\
\hline $\begin{array}{l}\text { Apis, } \% \text { : } \\
\text { compared with }\end{array}$ & 32.9 & $11 \cdot 9$ & $15 \cdot 3$ & 39.8 & & \\
\hline E, tenax, \%: & $\begin{array}{c}29 \cdot 1 \\
\text { (UL-ML) }\end{array}$ & $\begin{array}{l}19 \cdot 9 \\
(\mathrm{M})\end{array}$ & $\begin{array}{c}10 \cdot 5 \\
(\mathrm{MD})\end{array}$ & $\begin{array}{l}40 \cdot 5 \dagger \\
\text { (D) }\end{array}$ & & \\
\hline
\end{tabular}

* Figures in end-column are from "observations" in table 4.

† Figures in bottom row are from "collections" in table 3.

From a subjective assessment of the general brightness of the abdomen, the four Apis classes have been equated to Eristalis grades as follows: (i) $\mathrm{AD}=\mathrm{D}$; (ii) $\mathrm{AC}=\mathrm{MD}$; (iii) $\mathrm{AB} 1=\mathrm{M}$; (iv) $\mathrm{AB} 2=\mathrm{ML}, \mathrm{L}$, UL. Clearly defined light zones are present in the last two groupings, but not in the first two. Although measurements were never made for routine scoring, the markings usually occupy $5-9 \mathrm{~mm}^{2}$ of the exposed dorsal abdominal surface in AB1 bees and M Eristalis, but over $9 \mathrm{~mm}^{2}$ in AB2 and ML-UL 
specimens. $E$. tenax are slightly larger, and thus their markings take up a smaller proportion of the total dorsal surface, but this is balanced by slightly brighter colours.

Using this method of comparison, it is seen that there is a similar bimodality in honeybees at Keele and in samples of Eristalis tenax (males and females combined) collected in the same period. However the percentage of banded bees observed did vary between years (heterogeneity $\chi_{2}^{2}=$ $59.4, P<0.001$ ), and is not matched very closely by the percentage of lighter grades of $E$. tenax (UL-M) in each year.

\section{TABLE 7}

Field observations of Apis mellifera workers (simpler classification, 1973-76) and comparison with sympatric populations of $\mathrm{E}$. tenax

Area/Year

(a) Liverpool

1973
1974
1975
1976
Total $\dagger$

(b) Formby

$$
\text { 1973-75 }
$$

(c) Wirral

1973
1974
1975
Total $†$

(d) North Cheshire 1973-74

All sites combined
Apis mellifera workers

Banded

52
7
21
15
95

Dark

$\%$ banded
E. tenax* $\%$ UL, L, ML, M

$\begin{array}{rrr}145 & 26 \cdot 4 & 40 \cdot 0 \\ 68 & 9 \cdot 3 & 47 \cdot 8 \\ 59 & 26 \cdot 3 & 47 \cdot 6 \\ 16 & 48 \cdot 4 & 46 \cdot 0 \\ 288 & 24 \cdot 8 & 46 \cdot 1 \\ & & \\ 51 & 41 \cdot 4 & 47 \cdot 4 \\ 70 & 54 \cdot 5 & \\ 306 & 51 \cdot 1 & 54 \cdot 5 \\ 106 & 45 \cdot 1 & 55 \cdot 5 \\ 482 & 50.5 & 53.3 \\ & & 54 \cdot 2 \\ 10 & 77 \cdot 3 & \\ 831 & & 51 \cdot 3 \\ & 44 \cdot 1 & 47.9\end{array}$

* Figures from "observations" of E. tenax in table 4.

$\dagger$ Apis-heterogeneity amongst data from different years, Liverpool: $\chi_{3}^{2}=$ $19 \cdot 2(P<0 \cdot 001)$, Wirral: $\chi_{2}^{2}=3 \cdot 37(P>0 \cdot 1)$.

Earlier field observations in Merseyside and Cheshire (1973-1976) used a simpler scoring scheme (see table 7). For both Apis and E. tenax, lighter forms were less frequent at sites north of the Mersey than south of it. However individual estimates varied far more for Apis (9-77 per cent) than for $E$. tenax (40-56). One explanation is that the social life of bees limits their movements; at one site counts could be dominated by bees from a single hive. Hoverflies are not social and so can move more widely. When making comparisons, large numbers of honeybees from a wide area are needed. In fact, from tables 6 and 7, the overall proportion of banded Apis (44 per cent) is quite close to the 49 per cent of $E$. tenax with light brown or orange markings, and the correspondence between model and mimic was best where the sample size of bees was largest. 


\section{Discussion}

In the dronefly, Eristalis tenax, a genetic polymorphism is obscured by polygenic and environmental factors (Heal, 1979), and in natural populations it can be seen only as a bimodal distribution of patterns in each sex. Experiments with birds have shown that $E$. tenax are very palatable, but are sometimes rejected on sight because they are Batesian mimics of worker honeybees.

Mimicry of honeybees is quite common amongst flies active in spring because neither Bombus nor Vespula workers-other potential modelsare abundant until summer. British Syrphids which resemble honeybees include the larger Eristalis species active during most of the year (e.g., E. tenax and E. pertinax Scopoli) and some medium-sized species that have a single generation in spring (e.g., Cheilosia grossa Fallen, Epistrophe (Syrphus) eligans Harris). Of these species, E. tenax is the most variable.

Much of the variation in E. tenax is attributable to the corresponding genetic polymorphism in the model, Apis mellifera. Reports on the genetics of honeybees show that the factors controlling the coloration are the same as in E. tenax. Crosses between golden-banded and dark strains showed dominance of the light bands, although dominance was not complete (Kulincevic, 1967; Laidlaw and el-Banby, 1962). Some workers have suggested that further variability is due to several other genes being involved (see Roberts and Mackensen, 1951; Rothenbuhler et al., 1968). Soose (1954) showed that the extent of the abdominal bands is sensitive to temperature and so varies seasonally.

The honeybees of north-west England have a range of abdominal patterns, from completely dark to forms in which about half of the dorsal surface is orange. Sympatric populations of Eristalis tenax have a similar range, and both model and mimic have a bimodal distribution. In this study there were roughly 50 per cent with light markings in both species. The percentage of dark forms in the models and mimics observed was a little higher north of the river Mersey. However if a cline exists in E. tenax it is only a gradual one. Unless the two morphs differed in choice of habitat, the mobility of the flies would limit any local variation in gene frequency. On the other hand, honeybees live in large colonies of related insects and so local fluctuations in morph frequencies could occur if samples were derived from a few colonies only. Consequently, at a single site the data for models and for mimics do not always correspond closely with each other.

In spring, samples of female $E$. tenax were unimodal for intermediate patterns, not bimodal as in summer and autumn. An intermediate pattern receives greatest protection if predators generalise between two model patterns that are not greatly dissimilar. Generalisation is favoured while mimics remain scarce (see Holling, 1965; Heal, 1977).

In autumn, E. tenax outnumbered their models at many sites. For some birds, earlier experiences with sufficient bees would lead to aversion of all bee-like mimics. However, other birds will learn to discriminate visually between Eristalis and Apis (as in the experiments reported above), thus creating a selection pressure for close mimicry, and also variation, whilst mimics are abundant.

However, a "perfect" resemblance to bees has not evolved yet. Two explanations can be put forward for the light pattern of $E$. tenax consisting 
of paired spots rather than continuous bands as in Apis-firstly, partial wasp-mimicry, and secondly, thermoregulation.

Mostler's (1935) classic experiments showed that captive birds sometimes confused $E$. tenax with wasps. After being stung by a wasp, a flycatcher avoided many insects that were only crudely mimetic (Steiniger, 1937). Similarly, in my experiments, $E$. arbustorum got some protection from its moderate resemblance to a honeybee.

To improve the wasp-mimicry there seems to be an epistatic influence of the Ap gene on the hair colour genes (Heal, 1977). Dark Phenotype flies have hair colours varying from white to dark brown. However, on most Light Phenotype E. tenax the pubescence is light yellow, and seen most clearly as yellow bands along the sides of the thorax, where a wasp has stripes of yellow pigment. These lighter patterns would get less benefit from wasp-mimicry early in the year, before wasps are numerous. This could explain why L and UL grades were absent from spring samples. It may also explain why males, which appear later, tend to have brighter patterns than females, although differences in flight and behaviour may make wasp-mimicry more appropriate for males, as is the case in the sexually dimorphic Eristalis arbustorum (Heal, 1981).

Pigmentation can also have an important role in the control of body temperature. In the laboratory, pupal temperature influences the adult pattern, to give darker patterns at lower temperatures, both in $E$. tenax and $E$. arbustorum (Heal, 1977, 1981 and in preparation). The black areas down the centre of the abdomen of E. tenax (see fig. 1) may serve to absorb solar radiation and so warm the dorsal blood vessel that lies directly beneath. The usual basking position of Eristalis species, and also of many other large Diptera, is with the wings spread slightly so as to expose the middle of the abdomen. A black central stripe is a common feature in hoverflies. Honeybees lack this stripe and do not bask in sunshine.

On a global scale, geographical associations between brighter markings and hot climates are known for Apis mellifera (Rothenbuhler et al., 1968; Mace, 1976). Thus clines are to be expected in E. tenax, as a result of selection for both mimicry and thermoregulation. The mobility of adult flies limits the differentiation between populations in north-west England. Nevertheless the main factor in preserving phenotypic variation within populations is clearly Batesian mimicry of Hymenoptera.

Acknowledgments. - This work was greatly influenced by the helpful supervision of the late Professor Philip Sheppard. Thanks are also due to Mr J. K. Hulme, for the use of Ness Gardens, and to Julia Creighton, for criticism of the manuscript. Facilities were provided in the Genetics Department, Liverpool University - with finance from an S.R.C. studentshipand in the Department of Biological Sciences, Keele University.

\section{REFERENCES}

AUBERT, J., AUBERT, J.-J., AND GOELDLIN, P. 1976. Douze ans de captures systematiques de Syrphides (Diptères) au col de Bretolet (Alpes valaisannes). Bull. Soc. ent. Suisse, 49, $115-142$.

BAKER, R. R. 1978. The Evolutionary Ecology of Animal Migration, chapter 19, pp. 411-479. Hodder and Stoughton, London.

BROWER, J. 1960. Experimental studies of mimicry. IV. The reactions of starlings to different proportions of models and mimics. Am. Nat., 94, 271-282. 
BROWER, J., AND BROWER, L. P. 1962. Experimental studies of mimicry. 6. The reaction of toads (Bufo terrestris) to honeybees (Apis mellifera) and their dronefly mimics (Eristalis vinetorum). Am. Nat., 96, 297-307.

BROWER, J., AND BROWER, L. P. 1965. Experimental studies of mimicry. 8. Further investigations of honeybees (Apis mellifera) and their dronefly mimics (Eristalis spp.). Am. Nat., 99, 173-187.

COTT, н. в. 1936. The effectiveness of protective adaptations in the hive bee illustrated by experiments on the feeding reactions, habit formation and memory of the common toad (Bufo bufo bufo), Proc. zool. Soc. Lond., 1936, 111-133.

DAVIES, N. B., AND GREEN, R. E. 1976. The development and ecological significance of feeding techniques in the reed warbler (Acrocephalus scirpaceus). Anim. Behav., 24, 213-229.

DUNCAN, C. J., AND SHEPPARD, P. M. 1965. Sensory discrimination and its role in the evolution of Batesian mimicry. Behaviour, 24, 269-282.

HEAL, J. R. 1977. The genetic control of morphological and behavioural patterns in mimetic Syrphidae. Unpublished Ph.D. thesis, University of Liverpool.

HEAL, J. R. 1979. Colour patterns of Syrphidae: I. Genetic variation in the dronefly Eristalis tenax. Heredity, 42, 223-236.

HEAL, J. R. 1981. Colour patterns of Syrphidae. III. Sexual dimorphism in Eristalis arbustorum. Ecological Entomology, 6, 119-127.

HOLLING, C. S. 1965. The functional response of predators to prey density and its role in mimicry and population regulation. Mem. ent. Soc. Canada, 45, 5-60.

JONES, A. W. 1955. Dronefly visitors to the flowers of the city bombed sites. Lond. Nat., 34, $154-7$.

KENDALL, D. A., AND STRADLING, D. J. 1972. Some observations on overwintering of the drone fly, Eristalis tenax L. Entomologist, 105, 229-230.

KULINCEVIC, J. 1967. Über die Vererbung der Pigmentierung bei Arbeitsbienen von Apis mellifica L. und ihrer Kreuzungen. Ann. Abeille, 10, 103-117.

LAIDLAW, H. H., AND EL-BANBY, M. A. 1962. Inhibition of yellow body color in the honey bee Apis mellifera L. J. Hered., 53, 171-3.

LIEPELT, W. 1963. Zur Schutzwirkung des Stachelgiftes von Bienen und Wespen gegenüber Trauerfliegenschnäpper und Gartenrotschwanz. Zool. Jb. Physiol., 70, 167-176.

LUNDBECK, w. 1916. Diptera Danica. Part V: Lonchopteridae, Syrphidae. Gad, Copenhagen. MACE, H. 1976. The Complete Handbook of Bee-keeping. Ward Lock, London.

MOSTLER, G. 1935. Beobachtungen zur Frage der Wespenmimikry. Z. Morph. Oekol. Tierre, $29,381-454$.

POPHAM, E. J. 1948. Experimental studies of the biological significance of non-cryptic pigmentation with special reference to insects. Proc. zool. Soc. Lond., 117, 768-783.

ROBERTS, W. C., AND MACKENSEN, O. 1951. Breeding improved honey bees. II. Heredity and Variation. Am. Bee J., 91, 328-330.

ROTHENBUHLER, W. C., KULINCEVIC, J. M., AND KERR, W. E. 1968. Bee genetics. A. Rev. Gen., 2, 413-438.

SHEPPARD, P. M. 1975. Natural Selection and Heredity (4th edn.). Hutchinson, London.

SOOSE, E. 1954. Einfluss der Temperatur auf die Ausgestaltung von Flügelindex und Panzerfarbe der Honigbiene (Apis mell.) Arch. Bienenk., 31, 49-66.

STEINIGER, F. 1937. Beobachtungen und Bemerkungen zur Mimikryfrage. Biol. Z $b l$., 57, 47-58.

TURNER, J. R. G. 1977. Butterfly mimicry: the genetical evolution of an adaptation. Evolutionary Biology, 10, 163-206.

WILliAMS, C. B. 1958. Insect Migration. Collins, London. 